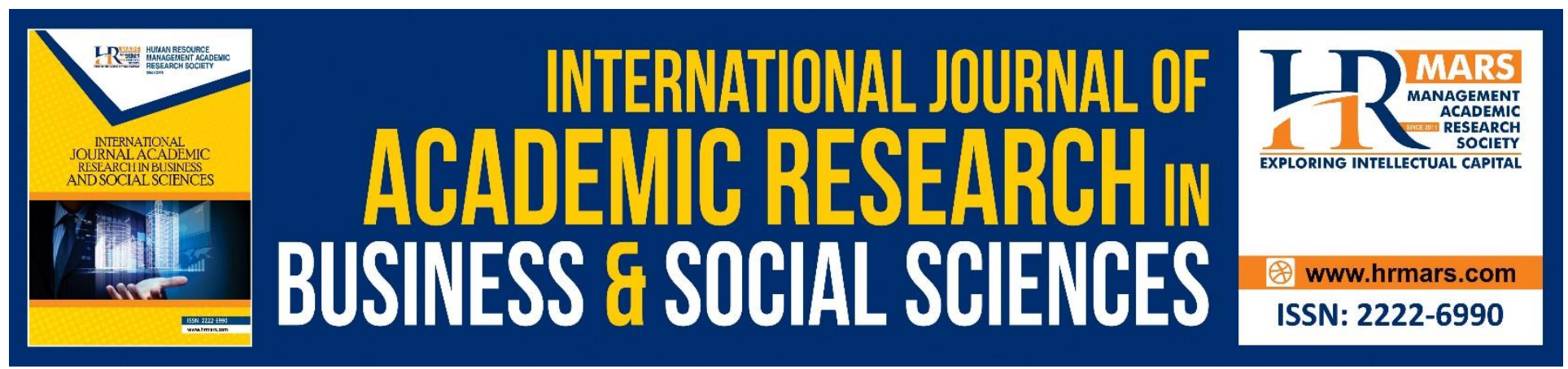

\title{
The Effects of Private Health Financing towards the Prevalence of Mental Health Problems: Case Study in Malaysia
}

\section{Zariyawati Mohd Ashhari, Diana Rose Faizal \& Tan Pei Wen}

To Link this Article: http://dx.doi.org/10.6007/IJARBSS/v10-i7/7433

DOI:10.6007/IJARBSS/v10-i7/7433

Received: 07 April 2020, Revised: 12 May 2020, Accepted: 17 June 2020

Published Online: 27 July 2020

In-Text Citation: (Ashhari \& Wen, 2020)

To Cite this Article: Ashhari, Z. M. D. R. F., \& Wen, T. P. (2020). The Effects of Private Health Financing towards the Prevalence of Mental Health Problems: Case Study in Malaysia. International Journal of Academic Research in Business and Social Sciences, 10(7), 432-445.

Copyright: (c) 2020 The Author(s)

Published by Human Resource Management Academic Research Society (www.hrmars.com)

This article is published under the Creative Commons Attribution (CC BY 4.0) license. Anyone may reproduce, distribute, translate and create derivative works of this article (for both commercial and non-commercial purposes), subject to full attribution to the original publication and authors. The full terms of this license may be seen

at: http://creativecommons.org/licences/by/4.0/legalcode

\section{Vol. 10, No. 7, 2020, Pg. 432 - 445}

Full Terms \& Conditions of access and use can be found at http://hrmars.com/index.php/pages/detail/publication-ethics 


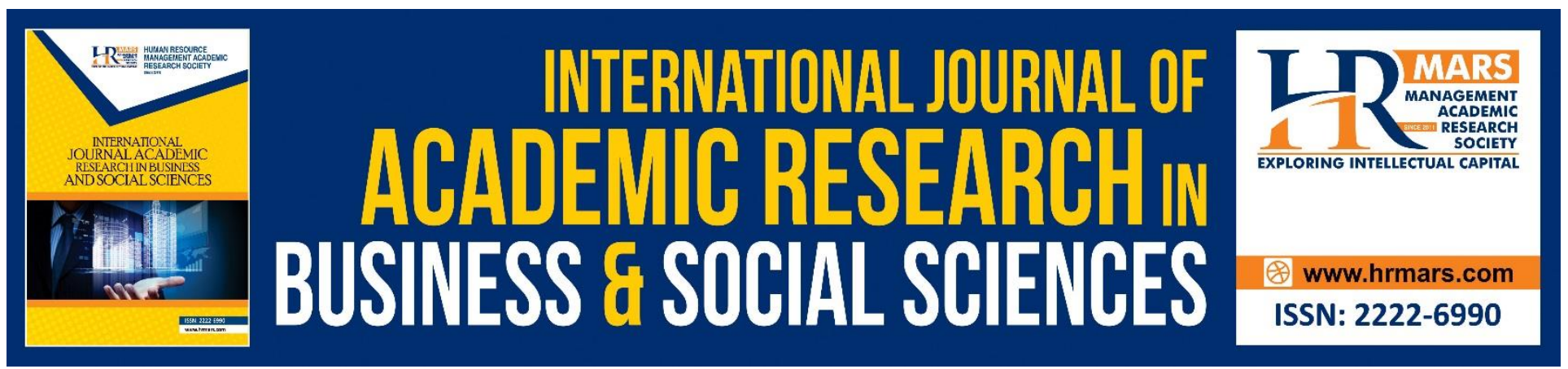

\title{
The Effects of Private Health Financing towards the Prevalence of Mental Health Problems: Case Study in Malaysia
}

\author{
Zariyawati Mohd Ashhari, Diana Rose Faizal \& Tan Pei Wen \\ School of Business and Economics, Universiti Putra Malaysia \\ Email: zariyawati@upm.edu.my
}

\begin{abstract}
This study examines the determinants of private health financing for the mental health of Malaysians. It investigates the relationship between socioeconomic status and the private health financing towards the mental health problem. In Malaysia, the rate of mental illness patients is increasing; with some form of mental illness affecting approximately 12 percent of Malaysians aged 18 to 60. It is believed that the lack of awareness and financial burden due to the increase in living costs is considered to be part-of the factor affecting the mental health in Malaysia. The results from the partial least square structural equation model (PLS-SEM) show a strong mediation between private health expenditure towards the relationship between socioeconomic status and mental health problem. Hence, these further strengthen that private health expenditure as importance factors related to mental health problem. Therefore, people should invest or spend some money for health expenditure in mitigating mental health problem in Malaysia.
\end{abstract}

Keywords: Private Financing, Health Financing, Mental Health Problem, Malaysia.

\section{Introduction}

Health is an idea that identifies and depicts a man's condition of being. In addition, health is combination of complete physical, mental and emotional, and social well-being. The ability to learn, work, accomplish our maximum capacity and enjoy our lives relies upon our wellbeing condition and along these lines sufficient medicinal services has turned into a crucial need for human prosperity (Hsiao et al., 2001). Therefore, health financing is being concerned in the world today. The main objective of health financing is to generate and allocated the use of financial resources in health systems. Health financing is needed to be specifically planned to let people access the sufficient quality of the health services. This will further ensure the user can enjoy health services without expose to financial hardship (World Health Report, 2010).

In most of the developing countries, health system is represented by combination of public and private health financing. In order to successfully manage health financing, it is fundamental to 
INTERNATIONAL JOURNAL OF ACADEMIC RESEARCH IN BUSINESS AND SOCIAL SCIENCES Vol. 10, No. 7, July, 2020, E-ISSN: 2222-6990 @ 2020 HRMARS

understand public health financing as well as private health financing. Public health financing is government expenditure on all activities related to health. The purpose of the public health financing is to promote physical and mental health and prevent disease, injury, and disability. Meanwhile, private health financing is individual expenditure or out of pocket money to spend on health such as medicine or supplement cost and insurance. In other words, private health financing had also being a supplement to the purpose of public health financing. Therefore, insufficient of health financing can affect individual health including mental health. On the other hand, well-organized mixed public and private health financing is fundamental of efficient health system. The world should pay close attention to private health financing instead of focus solely on public health financing.

Similarly, the demand of private health financing can determine the ability or wealth of public. It can be done by measuring their income and wealth. While economic inequality is believed to be another reason causing lower demand in private health financing known as individual health expenditure that being indirectly causing rising trend in mental health issues. Economic inequalities are most clearly shown by individual's different positions within the economic distribution such as income, pay and wealth. According to Hudson (2005), socioeconomic status are mostly use in measuring economic distribution and best explain in inverse relationship with mental health problems. In this study, we determine socioeconomic status such as income, level of education and occupation to identify their social class and their ability to pay for private health expenditure are linkage between mental health and socioeconomic status.

Further, an efficient health financing is able to affirm everyone equally entitled to the right to access the healthcare service. This indicates that health financing plays an important role in maintaining not only physical but also mental health. Ineffective health financing can be illustrated by data provided by WHO's Mental Health Atlas 2011. It demonstrates scarcity of resources to meet mental health need issues, inequitable distribution and inefficient use of such resources. As a result, in low and middle-income countries there are $76 \%$ to $85 \%$ of people suffer from severe mental disorders did not access to appropriate treatment for their disorder (WHO's Mental Health Atlas, 2011). Mental health problems are treated as one of the main factors of the burden of disease globally. Expectedly, similar issues faced in Malaysia where statistic has shown up to $10 \%$ of Malaysians are going to suffer from some form of mental illness when come year 2020. This follows on from a poll on National Health and Morbidity 2011 which indicate that 12\% of Malaysians already suffer from some form of psychological morbidity. In short, at least 1 in 10 Malaysians will face some mental ailment in their lifetime.

In reality, mental health services in Malaysia still insufficient to accommodate the whole request from the community currently where we have 671 health clinics and 22 mental health centers only to provide mental health services in the country (New Strait Times, 2016). This determines that current investment in mental health services is far lower than what is needed. In public healthcare system, long appointment queues are more likely reasons why patients reluctant to seek professional help. The waiting time is even longer when manpower is limited in public hospital. This situation is contract in private hospital. People are more likely to enjoy health treatment in private hospitals or facilities as it relatively quicker process but with higher fee. Hence, this will increase their health expenditure. As a result, individual or household health expenditure spending pattern will be influenced. They 
need to increase or put aside some money from their income for health expenditure such as medical insurance, medicine and supplement as to keep their physical and mental health in good condition. This can be supported by a study from Galbraith, Wong, Kim \& Newacheck, (2005) and Hui, Chui \& Woo (2009) that highlighted people who access to private health financing and leisure expenditure can help to substantially influence the prevalence of mental health.

Nonetheless, not everyone concerned about this matter which they ignore the importance on health expenditure. This is because they cannot afford to spend on health financing. A number of studies has shown that high and increasing health financing has caused to poor spending on health expenditure. People are suffered from health expenditure in seeking healthcare services has consequently impacted their well-being. As said by the Mishra \& Mohanty (2009), poor people spending on health financing can become poorer people. Hence, they prefer to use their income for the most important of basic needs like foods. To conclude, people forgo the importance of private health financing due to the limited and insufficient income. This difficulty will affect the quality of life if this happens continuously. Thus, the objective of this study is to examine the relationship between socioeconomic status (SES), private health financing and mental health problems.

\section{Theoretical Background}

There are three main indicator of socioeconomic status (SES) that are income, education level and occupation is highly correlated with mental health status (Stenmark, 2016; Hudson, 2005 ; Franz, Lensche, \& Schmitz, 2002 ; Hudson, 1988). Besides, according to Boe, Overland, Lundervold, \& Hysing (2012), they confirmed there is an inverse relationship between SES and mental health problems in place of poor family economy consistently predicted mental health problems. Therefore, it shows that poverty's damage occurs at multiple levels. Low socioeconomic status of poor families' state vulnerable to risky and unsafe neighborhoods, more crowded house, more conflict and instability in the family, and polluted air and water (Evans, 2004). These multiple risks, in turn, affect children and adults leading to an array of psychological and physical morbidity. As seen in Figure 1 , the framework shows that interrelationship between SES, private health financing and mental health problem.

SES is one of the useful elements to investigate the prevalence of mental health problems. Araya, Lewis, Rojas \& Fritsch (2003) have studied about how socio-demographic factors influenced the prevalence of mental health problems. They found a higher prevalence of mental health problems occurred among the most socially disadvantaged groups especially those married females with lower education and low income. Additionally, previous researchers also argued that elderly, female, lowincome groups are categorized under the higher risk to suffer from mental health problems (Noorbala, Bagheri \& Hafezi, 2012). For example, when people who have low education level, lowincome level, he might live in high pressure which this leads to higher prevalence of mental disorders. Conversely, if adults who are high education level, high-income level, he might enjoy his life with limited pressure which this leads to the lower prevalence of mental disorders. In addition, education level and occupation have been argued in a study of King \& Hegadoren (2002). They state that different occupation and different education level might influence our mental well-being. They also claimed that teacher might suffer from mental health problems such as stress, depressions and also anxiety. This can be supported by later study done by Weber, Weltle \& Lederel (2005). They reveal 
INTERNATIONAL JOURNAL OF ACADEMIC RESEARCH IN BUSINESS AND SOCIAL SCIENCES

Vol. 10, No. 7, July, 2020, E-ISSN: 2222-6990 @ 2020 HRMARS

that mental illness among teachers has become an increasing problem in many countries. It is one of the stressful jobs as a working environment for teachers is highly stress-provoking (Sveinsdottir, Gunarsdottir, and Fridriksdottir, 2007). Therefore, this shows a strong association between SES and mental disorders. Thus, it is hypothesized that:

H1: Socio-economic status (SES) is negatively related to mental health problems.

According to previous studies, SES work as elements to influenced households decisions on private health financing (Mitchell \& Utkus, 2006). For example, adults with higher income will be willing to spending more on private health financing such as taking a supplement and purchase private medical insurance. On the other hands, according to da Silva, Barros, Bertoldi, de Andrade Jacinto, Matijasevich, Santos, \& Tejada (2015), there are different spending pattern on private health expenditure for high and low-income family. For instance, low-income families are willing to spend more on medicine whereas high-income family are mostly on monthly premiums for private health insurance. This reflected that a better off SES would lead to higher consumptions in private health financing. Thus, it can hypothesize that:

H2: Socio-economic status (SES) is positively related to private health financing.

The primary purpose of private health financing is intended to cover all forms of health care expenses that are not funded by the government. For example, private health insurance is projected to protect people by shifting unpredictable health care cost to fixed premiums (Griffin, 1992). Thus, health financing plan is necessary for every family as it has been documented that insurance coverage improves access and use of healthcare service for low-income families (Galbraith et al., 2005). Besides, with insurance coverage, people do not need to worry about medical fees when there are accidents happened. This will, in turn, reduced the feeling of anxiety as private health insurance bring a sense of solace. Such expenses take into consideration pooling of risks and prompts a low likelihood of cataclysmic expenses that can result in diminishing poverty for the household (WHO, 2006). Therefore, higher expenditure on private health financing will, in turn, reducing the prevalence of mental health problems. Therefore, the hypothesize as proposed:

H3: Private health financing is negatively related to mental health problems.

Getting an efficient private health financing plan is essential key for every household today. This can be explained by the study of Giedion, Alfonso, \& Díaz (2013), they suggested health financing plan should not target the poor only, but also need to keep an eye on the non-poor. On the other hands, Waters, Anderson \& Mays (2004) state that higher income families appear likely to be protected by healthcare expenditure compared with poor families. This might due to high-income families manage to pay the health insurance premium. Consequently, they will feel stress less as health insurance is going to cover their medical fees. There is also evidence that health insurance can relieve financial burdens on individual households (Miller, Pinto, \& Vera-Hernández, 2009), as a result, leads to the lower prevalence of poor mental health. Thus, this hypothesizes as proposed:

H4: Private health financing mediates the relationship between socio-economic status and mental health problems. 


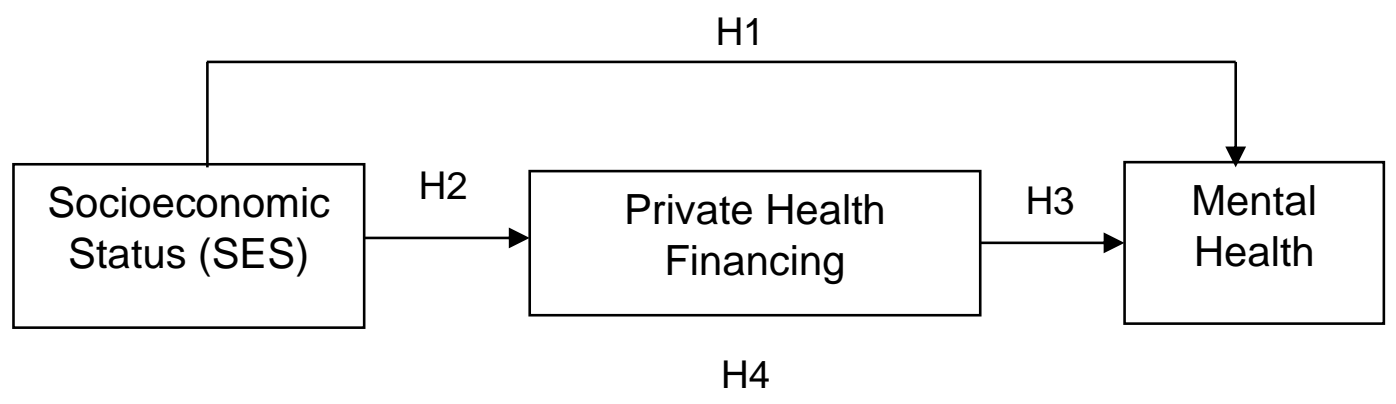

\section{Methodology}

The study used quantitative design to analyses how the impact of socioeconomic status and private health financing effects to mental health. Thus, the target population of this study was a labour force who is employed in Malaysia. The employed people were selected based on who worked at least one hour for pay, profit or family gain (as employer, employee, own-account worker or unpaid family worker). They are chosen because of their participation and the freedom to make decisions because they earn income to fulfill their living. Thus, a household in Malaysia who are employed were considered as the sample size of this study. According to Department of Statistics Malaysia (2017), the total number of population in Malaysia is 32 million. The labour force participation rate is $67.7 \%$ in 2017. This indicates that the total labour is $14,941,500$ million. However, a definition of labour force in Department of Statistics Malaysia refers to those in 15 to 64 years and who are either employed or unemployed. Hence this study only focused on the labour force who is employed in Malaysia. Thus, a number of 384 of respondent needed for this study (Krejcie and Morgan, 1970). However, since the number of population is outranged, to more emphasized and avoiding the bias, a total of 796 respondent being collected in duration of 6 months. Hence, this study managed to covered Peninsular (four regions of states) and East Malaysia (Sabah and Sarawak). The study was focused on the mental health issues. Thus, this study used self-administrated questionnaire. The questions on mental well-being derived from the DASS-21 item (Depression, Anxiety, Stress Scale) by Lovibond \& Lovibond, (1995) and questions related to private health financing derived from the study by (Munisamy, et.al.,2018). After collecting the questionnaires, the data collected was analyzed using PLS-SEM. Through the test on the objectives, it go through the data screening, statistical analysis on descriptive statistics and lastly the assessment of structural model.

\section{Result and Discussion}

The demographic characteristics of respondents are shown in Table 1. All of the 796 respondents were Malaysian since this study attempt to investigate the Malaysia household's employed. 
INTERNATIONAL JOURNAL OF ACADEMIC RESEARCH IN BUSINESS AND SOCIAL SCIENCES Vol. 10, No. 7, July, 2020, E-ISSN: 2222-6990 @ 2020 HRMARS

Table 1: Demographic Characteristics

\begin{tabular}{|c|c|c|c|c|}
\hline No & Demographic Value & $\begin{array}{l}\text { Number of } \\
\text { Respondents }\end{array}$ & $\begin{array}{c}\text { Percentage } \\
\text { (\%) }\end{array}$ & $\begin{array}{l}\text { Cumulative } \\
\text { percentage (\%) }\end{array}$ \\
\hline \multirow[t]{3}{*}{1.} & Gender & & & \\
\hline & Male & 280 & 35.2 & 35.2 \\
\hline & Female & 516 & 64.8 & 100.0 \\
\hline \multirow[t]{8}{*}{2.} & Age & & & \\
\hline & $<26$ years old & 226 & 28.4 & 28.4 \\
\hline & 26 to 30 years old & 150 & 18.8 & 47.2 \\
\hline & 31 to 35 years old & 133 & 16.7 & 63.9 \\
\hline & 36 to 40 years old & 108 & 13.6 & 77.5 \\
\hline & 41 to 45 years old & 64 & 8.0 & 85.6 \\
\hline & 46 to 55 years old & 89 & 11.2 & 96.7 \\
\hline & $>55$ years old & 26 & 3.3 & 100.0 \\
\hline \multirow[t]{5}{*}{3.} & Race & & & \\
\hline & Malay & 460 & 57.8 & 57.8 \\
\hline & Chinese & 211 & 26.5 & 84.3 \\
\hline & Indian & 43 & 5.4 & 89.7 \\
\hline & Others & 82 & 10.3 & 100.0 \\
\hline \multirow[t]{6}{*}{4.} & Education Level & & & \\
\hline & No Formal Education & 16 & 2.0 & 2.0 \\
\hline & School Certificate & 188 & 23.6 & 25.6 \\
\hline & Diploma & 118 & 14.8 & 40.4 \\
\hline & Bachelor Degree & 205 & 25.8 & 66.2 \\
\hline & Post-graduate & 269 & 33.8 & 100.0 \\
\hline \multirow[t]{4}{*}{5.} & Marital Status & & & \\
\hline & Single & 380 & 47.7 & 47.7 \\
\hline & Married & 386 & 48.5 & 96.2 \\
\hline & Divorce/ separate & 30 & 3.8 & 100.0 \\
\hline \multirow[t]{5}{*}{6.} & Income & & & \\
\hline & $<\mathrm{RM} 3000$ & 366 & 46 & 46.0 \\
\hline & RM 3000 - 4999 & 152 & 19.1 & 65.1 \\
\hline & RM 5000- 6999 & 116 & 14.6 & 79.6 \\
\hline & $>$ RM 7000 & 162 & 20.3 & 100.0 \\
\hline \multirow[t]{6}{*}{7.} & Occupation & & & \\
\hline & Self- employed & 119 & 14.9 & 14.9 \\
\hline & Non-executive & 209 & 26.2 & 41.2 \\
\hline & Executive & 160 & 20.1 & 61.2 \\
\hline & Professional & 265 & 33.3 & 94.6 \\
\hline & Others & 43 & 5.4 & 100.0 \\
\hline \multirow[t]{4}{*}{8.} & Current working state & & & \\
\hline & Kuala Lumpur & 42 & 5.3 & 5.3 \\
\hline & Labuan & 6 & .8 & 6.0 \\
\hline & Putrajaya & 7 & .9 & 6.9 \\
\hline
\end{tabular}


INTERNATIONAL JOURNAL OF ACADEMIC RESEARCH IN BUSINESS AND SOCIAL SCIENCES

Vol. 10, No. 7, July, 2020, E-ISSN: 2222-6990 @ 2020 HRMARS

Johor

Kedah

Kelantan

Melaka

Negeri Sembilan

Pahang

Perak

Perlis

Pulau Pinang

Sabah

Sarawak

Selangor

Terengganu
16

22

18

37

33

16

8

30

96

53

184

172

56
2.0

2.8

2.3

4.6

4.1

2.0

1.0

3.8

12.1

6.7

23.1

21.6

7.0
8.9

11.7

13.9

18.6

22.7

24.7

25.8

29.5

41.6

48.2

71.4

93.0

100.0

$\mathrm{N}=796$

Descriptive analysis of constructs studied based on the descriptive statistical data, such as mean, standard deviation and variance. By using the statistical software SPSS, the result of descriptive analysis is shown in Table 2. The standard deviations for all constructs were lower than 1.00, which indicates the score variation and distribution of the mean value was small. This implies that the respondents have a common perception of the aspects of this study.

Table 2 Descriptive Analysis on construct

\begin{tabular}{cccc}
\hline Construct & Mean & Std. Dev. & Variance \\
\hline 1. DAS & 2.3702 & .76106 & .579 \\
2. Health Financing & 2.6649 & .87502 & .766 \\
\hline
\end{tabular}

\section{Assessment of Measurement Model}

PLS-SEM is used to assess the measurement and structural model for this study. This part discusses the assessment of measurement model which deliberate on the internal consistency reliability, indicator reliability, convergent validity and discriminant validity. Table 3 shows the revised measurement model for this study. 
INTERNATIONAL JOURNAL OF ACADEMIC RESEARCH IN BUSINESS AND SOCIAL SCIENCES Vol. 10, No. 7, July, 2020, E-ISSN: 2222-6990 @ 2020 HRMARS

Table 3 Measurement Model Evaluation Result

\begin{tabular}{|c|c|c|c|c|}
\hline Construct & Items & Loading & CR & AVE \\
\hline \multirow[t]{3}{*}{ DASS-21 } & Depression & 0.882 & 0.903 & 0.756 \\
\hline & Anxiety & 0.867 & & \\
\hline & Stress & 0.859 & & \\
\hline \multirow{18}{*}{$\begin{array}{l}\text { Private Health } \\
\text { Financing }\end{array}$} & HF1: I spend part of my salary/ income on & & & \\
\hline & $\begin{array}{l}\text { care that required staying overnight in a } \\
\text { hospital or health facility. }\end{array}$ & 0.781 & 0.929 & 0.502 \\
\hline & HF2: I spend part of my salary / income on & & & \\
\hline & $\begin{array}{l}\text { care by doctors, nurses, or trained } \\
\text { midwives that did not require an overnight } \\
\text { stay. }\end{array}$ & 0.781 & & \\
\hline & $\begin{array}{l}\text { HF3: I spend part of my salary / income on } \\
\text { care by traditional or alternative healers. } \\
\text { (e.g. massage, acupuncture, etc.) }\end{array}$ & 0.673 & & \\
\hline & $\begin{array}{l}\text { HF4: I spend part of my salary / income on } \\
\text { dentists. }\end{array}$ & 0.732 & & \\
\hline & $\begin{array}{l}\text { HF5: I spend part of my salary / income on } \\
\text { medication and health supplement }\end{array}$ & 0.694 & & \\
\hline & $\begin{array}{l}\text { HF6: I spend part of my salary / income on } \\
\text { health care products such glasses, hearing } \\
\text { aids, prosthetic devices, lucose strips, } \\
\text { lancet etc. }\end{array}$ & 0.678 & & \\
\hline & $\begin{array}{l}\text { HF7: I spend part of my salary / income on } \\
\text { medical checkup, diagnostic and }\end{array}$ & & & \\
\hline & $\begin{array}{l}\text { laboratory tests such as X-rays, blood tests } \\
\text { etc. }\end{array}$ & 0.757 & & \\
\hline & HF8: I spend part of my salary / income on & & & \\
\hline & $\begin{array}{l}\text { any other health care products or services } \\
\text { that were not included above. }\end{array}$ & 0.731 & & \\
\hline & $\begin{array}{l}\text { HF9: I pay my health expenditure by } \\
\text { current salary / income. }\end{array}$ & 0.616 & & \\
\hline & $\begin{array}{l}\text { HF10: I pay my health expenditure by } \\
\text { savings (e.g. bank account etc.) }\end{array}$ & 0.772 & & \\
\hline & HF11: I pay my health expenditure by & & & \\
\hline & $\begin{array}{l}\text { payment or reimbursement from a health } \\
\text { insurance plan }\end{array}$ & 0.565 & & \\
\hline & $\begin{array}{l}\text { HF12: I pay my health expenditure (e.g. } \\
\text { huge medical debt: hospitality for long } \\
\text { term etc.) by sold items (e.g. jewelry, } \\
\text { house, vehicle etc.) }\end{array}$ & 0.728 & & \\
\hline & $\begin{array}{l}\text { HF13: I pay my health expenditure by loan } \\
\text { from someone others. }\end{array}$ & 0.670 & & \\
\hline
\end{tabular}


INTERNATIONAL JOURNAL OF ACADEMIC RESEARCH IN BUSINESS AND SOCIAL SCIENCES Vol. 10, No. 7, July, 2020, E-ISSN: 2222-6990 @ 2020 HRMARS

\begin{tabular}{lllll}
\hline Socioeconomic & Occupation & 0.769 & 0.871 & 0.692 \\
status & Income & 0.832 & & \\
& Education & 0.890 & & \\
\hline
\end{tabular}

\section{Internal Consistency Reliability}

According to Hair et al. (2014), the acceptable composite reliability of each construct at the value of 0.7. However, Gefan, Straub \& Boudreau (2000) states that values greater than 0.60 is also acceptable in exploratory study. Thus, result shown in Table 3, composite reliability value is more than 0.70 , socioeconomic status (0.871), health financing $(0.929)$ and mental health $(0.9203)$. This result shows that the value is more desirables as it is more than 0.80 .

\section{Indicator Reliability}

A study by Robinson, Shaver and Wrightsman (1991) mentioned that when average variance extracted (AVE) greater than 0.5 than the factor loading is acceptable at more than 0.60 . However, value less than 0.50 is removed from the measurement model in order to improve the assessment of convergent and discriminant validity. Table 3 shows the result of each item that be tested in the study.

\section{Convergent Validity}

Hair et al (2014) justify that the average variance extracted (AVE) value is adequate at least 0.50 or more. Table 4.3 shows that the convergent validity is more than 0.50 , socioeconomic status (0.692), private health financing $(0.502)$ and mental health $(0.756)$. Thus, the measurement of construct are related to each other.

\section{Discriminant Validity}

In this study, only assessment by Fornell Larcker (1981) is being tested. A measurement model has discriminant validity when all square roots AVE exceeded the off-diagonal elements in their corresponding row and column. Table 4 represent the square roots of the AVE and non-bolded values represents the intercorrelation value between constructs.

Table 4 Discriminant Validity

\begin{tabular}{|l|r|l|l|}
\hline & Mental Health & PHF & SES \\
\hline Mental Health & $\mathbf{0 . 8 6 9}$ & & \\
\hline PHF & 0.288 & $\mathbf{0 . 7 0 9}$ & \\
\hline SES & -0.22 & -0.262 & $\mathbf{0 . 8 3 2}$ \\
\hline
\end{tabular}

\section{Assessment of Structural Model}

The following sections discuss the tests used to assess the validity of the structural model. This process assessed the path coefficient. This was also assess the mediating relationship that are being proposed in the research model. 
INTERNATIONAL JOURNAL OF ACADEMIC RESEARCH IN BUSINESS AND SOCIAL SCIENCES

Vol. 10, No. 7, July, 2020, E-ISSN: 2222-6990 @ 2020 HRMARS

Figure 2 Structural Model

In PLS-SEM, each path connecting two variables represented a hypothesis (Hair et al., 2014). Thus,

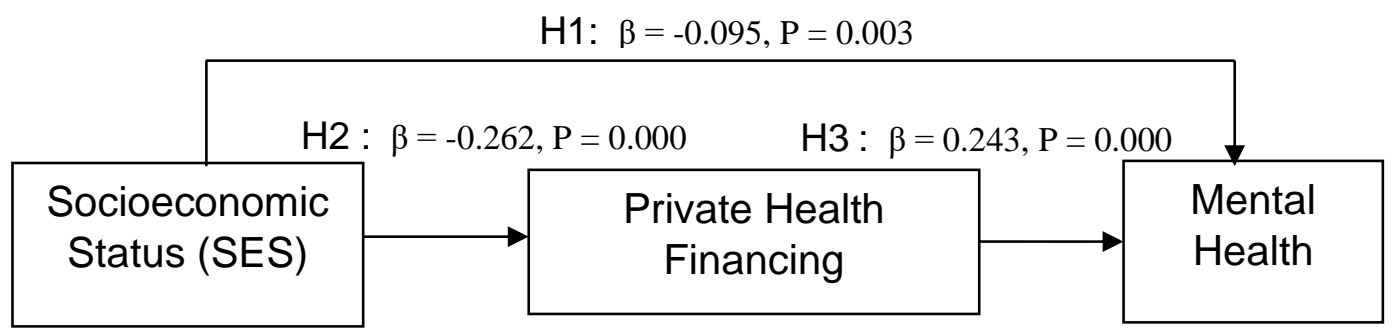

$H 4: \beta=-0.065, P=0.000$

Figure 2 shows the result of path coefficient at the significant level of 95 percent confidence interval with $\mathrm{p}$-value less than 0.01. Hypothesis 1 revealed that socioeconomic status is negative and significantly related to mental health problems $(\beta=-0.095$, $\mathrm{t}$-value $=2.778)$. The result shows that lower education and lower income are classified according to the higher risk of mental health problems. The same goes for the occupation, a type of job offered could affect your mental wellbeing. This would be terribly more if the person who receives less money could suffer from depression, stress and anxiety. The concept in line with previous researcher (Noorbala, Bagheri, \& Hafezi, 2012; Chang-Quan et al., 2010), who reflected that how low socio-demographic factors influenced the prevalence of mental health problems in Malaysia.

Hypothesis 2 revealed that socioeconomic status is significantly relationship with private health financing $(\beta=-0.262, P=0.000)$. However, it shows that socioeconomic status has a negative relationship with influenced on private health financing. High or low income family in Malaysia would not be preferable to spend on private health financing. They are less likely to spend on health when their company covered health insurance for workers. Besides, the results show that the household spending on public health financing is more preferable. Even for the long awaited queue, public health in Malaysia could41 provide better services with subsidy prices. However, households are less aware of private health financing, as they focus more on other things that could benefit others compared to the importance of health. Nevertheless, a household with a higher education (degree/bachelor) would not spend part of its salary on meeting doctors without sickness, purchasing additional healthcare products and allocating part of its salary to health expenditure. They would spend more on their luxury, such as buying cars, houses, electronics and many more that are not related to health spending.

Hypothesis 3 revealed that private health financing is positively and significantly relationship with mental health problem $(\beta=0.243, P=0.000)$. Therefore, households in Malaysia do not spend on private health financing that increases mental health problem. This is inline, from the Mental Health Atlas of the World Health Organization (2011), households suffering from mental disorders do not have access to appropriate treatment. Thus, indirectly misconception of mental health as a result increase the number of social stigma. The public is less in favor of the element of private health financing. As they haven't seen, treatment and health supplement really help people live long term. 
While the mediating effect relationship supported at a level of 95 per cent confidence interval with a p-value less than 0.01 (Preacher and Hayes 2008). The results of the bootstrapping analysis show that hypothesis 4 , public health financing mediates the relationship between socioeconomics and mental health problems $(\beta=-0.065, P=0.000)$. Therefore, private health financing is proposed to have a significant effect on reducing the prevalence of mental health problems in Malaysia. It shows how important it could help reduce the prevalence of mental health problems by spending private health financing. In Malaysia, however, the government and private parties are less active in the promoting health system, which is still inefficient, ineffective and unapproachable to people, particularly in the area of mental health.

\section{Conclusion}

\section{Theoretical Implication}

The present study aim to close the gap of literature on the effect of socioeconomic status towards private health financing and leisure expenditure and its consequence on prevalence of mental health problems. Despite of various studies of impacts of mental health problems, there has been lack of research concerning the factors influencing mental health problems. In order to reduce the number of prevalence of mental health problems, is a must to understand what the influencer indicators are. On the other hands, the study contributes significantly to the body of knowledge. Private health financing, this variable has less been studied in past studies due to majority of studies frequently highlights public health financing in their study. Meanwhile, this study will be done in Malaysia context. Malaysia health system are combination of public health financing and private health financing. As a dual health system country, Malaysia is a good study field to prove the effectiveness of proposed framework in this study.

\section{Practical Implication}

The study aim to offer guide to community, academic, government and related private healthcare sector. First of all, the finding of the study will help to reduce social stigma problems. The present study explain important factors highly affecting public's mental health problems; educate and intended to change public's attitude towards mental illness patients. In addition, the study will provide insight to assist the government in policy making as well as to emphasize the importance of health financing distribution on development of mental healthcare service. The policy maker should take care of the citizens who live in rural area that hard to access to reach professional treatment. Lastly, the study will also be a source of reference material for those seeking mental healthcare services. This study also provides evidence to help citizens and mental health patients in decision making for their finance resources investment. Throughout the study, people can recognize the effects of private health financing toward their health purpose. Until now, there is limited study on the impact of private health financing, toward reducing prevalence of mental health. The present research enrich the existing literature by providing evidence regarding the effect of private health financing and leisure expenditure on the prevalence of mental health in the Malaysia.

\section{Acknowledgement}

This project was supported by a GP-IPS grant from Universiti Putra Malaysia (UPM), award number GP-IPS/2017/9548900. The content is solely the responsibility of the authors and does not necessarily represent the official views of the UPM. 
INTERNATIONAL JOURNAL OF ACADEMIC RESEARCH IN BUSINESS AND SOCIAL SCIENCES

Vol. 10, No. 7, July, 2020, E-ISSN: 2222-6990 @ 2020 HRMARS

\section{References}

Araya, R., Lewis, G., Rojas, G., \& Fritsch, R. (2003). Education and income: which is more important for mental health?. Journal of Epidemiology and Community Health, 57(7), 501-505.

Da Silva, M. T., Barros, A. J., Bertoldi, A. D., Jacinto, D. A. P., Matijasevich, A., Santos, I.

S., \& Tejada, C. A. O. (2015). Determinants of out-of-pocket health expenditure on children: an analysis of the 2004 Pelotas Birth Cohort. International journal for equity in health, 14(1), 53.

Dohrenwend, B. P. (1980). Mental health in the United States: Epidemiological estimates. New York: Praeger.

Evans, G. W. (2004). The environment of childhood poverty. American psychologist, 59(2), 77.

Franz, M., Lensche, H., \& Schmitz, N. (2003). Psychological distress and socioeconomic status in single mothers and their children in a German city. Social psychiatry and psychiatric epidemiology, 38(2), 59-68.

Galbraith, A. A., Wong, S. T., Kim, S. E., \& Newacheck, P. W. (2005). Out-of-Pocket Financial Burden for Low-Income Families with Children: Socioeconomic Disparities and Effects of Insurance. Health services research, 40(6p1), 1722-1736.

Giedion, U., Alfonso, E. A., \& Díaz, Y. (2013). The impact of universal coverage schemes in the developing world: a review of the existing evidence. Washington, DC: World Bank.

Griffin, C. C. (1992). Health care in Asia: a comparative study of cost and financing.

Hudson, C. G. (2005). Socioeconomic status and mental illness: tests of the social causation and selection hypotheses. American journal of Orthopsychiatry, 75(1), 3.

Hudson, C. G. (1988). The social class and mental illness correlation: Implications of the research for policy and practice. J. Soc. \& Soc. Welfare, 15, 27.

Hui, E., Chui, B. T. K., \& Woo, J. (2009). Effects of dance on physical and psychological weel-being in older persons. Archives of Gerontology and Geriatrics, 49(1), e45-e50.

King, S. L., \& Hegadoren, K. M. (2002). Stress hormones: how do they measure up?. Biological research for nursing, 4(2), 92-103.

Lovibond, P. F., \& Lovibond, S. H. (1995). The structure of negative emotional states: Comparison of the Depression Anxiety Stress Scales (DASS) with the Beck Depression and Anxiety Inventories. Behaviour research and therapy, 33(3), 335-343.

Krejcie, R. V., \& Morgan, D. W. (1970). Determining sample size for research activities. Educational and psychological measurement, 30(3), 607-610.

Miller, G., Pinto, D. M., \& Vera-Hernández, M. (2009). High-powered incentives in developing country health insurance: evidence from Colombia's Régimen Subsidiado. National Bureau of Economic Research.

Mishra, S., \& Mohanty, S. K. (2019). Out-of-pocket expenditure and distress financing on institutional delivery in India. International Journal for Equity in Health, 18(99), 1-15.

Mitchell, O. S., \& Utkus, S. P. (2006). How behavioral finance can inform retirement plan design. Journal of Applied Corporate Finance, 18(1), 82-94.

Munisamy, M., Thanapalan, T., Piwong, P., Panza, A., \& Pongpanich, S. (2018). Assessment of the validity and reliability of an urban household health expenditure (HHE) questionnaire in Kuala Lumpur, Malaysia. Journal of Health Research.

Noorbala, A. A., Bagheri, Y. S. A., \& Hafezi, M. (2012). Trends in change of mental health status in the population of Tehran between 1998 and 2007. Arch Iran Med, 15, 201-204. 
INTERNATIONAL JOURNAL OF ACADEMIC RESEARCH IN BUSINESS AND SOCIAL SCIENCES

Vol. 10, No. 7, July, 2020, E-ISSN: 2222-6990 @ 2020 HRMARS

Stenmark, H., Bergström, E., Hägglöf, B., Öhman, A., \& Petersen, S. (2016). Mental problems and their socio-demographic determinants in young schoolchildren in Sweden, a country with high gender and income equality. Scandinavian journal of public health, 44(1), 18-26.

Sveinsdottir, H., Gunnarsdóttir, H., \& Friðriksdóttir, H. (2007). Self-assessed occupational health and working environment of female nurses, cabin crew and teachers. Scandinavian journal of caring sciences, 21(2), 262-273.

Waters, H. R., Anderson, G. F., \& Mays, J. (2004). Measuring financial protection in health in the United States. Health Policy, 69(3), 339-349.

Weber, A., Weltle, D., \& Lederer, P. (2005). III health and early retirement among school p principals in Bavaria. International archives of occupational and environmental health, 78(4), 325-331. 